REPORTS OF MORPHOLOGY
Official Journal of the Scientific Society of Anatomists,
Histologists, Embryologists and Topographic Anatomists
of Ukraine
journal homepage: https://morphology-journal.com

\title{
Immunohistochemical features of expression and distribution of antibodies to thyroglobulin in the thyroid glands of newborn rats after prenatal exposure of dexamethasone
}

\section{Fedosieieva O.V., Pototska O.I.}

Zaporizhzhia State Medical University, Zaporizhzhia, Ukraine

\section{ARTICLE INFO}

Received: 18 December, 2020

Accepted: 20 January 2021

UDC: $612.44 .014: 616.441-71-089.85$

\section{CORRESPONDING AUTHOR}

e-mail: fedoseeva.ov.1@gmail.com Fedosieieva O.V.
In clinical practice, synthetic glucocorticoids, such as dexamethasone, are used to accelerate fetal maturation in pregnant women at risk of preterm birth. Increasing the concentration of cortisol in humans and other mammals often causes structural and functional changes in fetal tissues, preparing it for childbirth and extrauterine life, but they can have long-term consequences in the structural organization of organs postnatally. Despite the large number of studies on the effect of glucocorticoids on the fetus, there are almost no data on the prenatal effect of dexamethasone on the processes of synthesis and resorption of thyroglobulin by thyroid thyrocytes in the postnatal period of life. Therefore, the aim of the study was to determine the immunohistochemical features of expression and distribution of antibodies to thyroglobulin in the thyroid glands of newborn rats in normal and after prenatal exposure to dexamethasone. The study material was the thyroid gland of Wistar rats aged 1 to 7 days of postnatal development (54 animals): I group - intact animals (norm); II group - control, animals which were injected with $0.9 \% \mathrm{NaCl}$ solution at a dose of $0.05 \mathrm{ml}$ to each fetus on the 18th day of dated pregnancy; III group - experimental animals, which were administered a solution of dexamethasone at a dilution of 1:40 at a dose of $0.05 \mathrm{ml}$ to each fetus on the 18th day of the date of pregnancy operatively during laparotomy, by intrauterine, transdermal subcutaneous injection into the interscapular area (Ukrainian patent №112288). Thyroglobulin Antibody (2H11) monoclonal antibodies: sc-51708 from Santa Cruz Biotechnology, Inc. were used for immunohistochemical study. Photo documentation of the studied objects was performed using a "Primo Star" microscope (Carl Zeiss, Germany) using an AxioCam camera using the Zeiss Zen program (2011). Analysis of micropreparations of thyroid glands of intact and control rats showed invariance of thyroglobulin synthesis and its accumulation, which was expressed by sufficient immunohistochemical expression of antibodies to thyroglobulin $\left(\mathrm{TgAb}{ }^{+}\right)$. Prenatal administration of dexamethasone leads to intensification of the processes of morphological development of hormone-producing structures (follicles and follicular epithelium), production, resorption and iodination of thyroglobulin. This is evidenced by immunohistochemical studies found in 1-3 days of the neonatal period. It should be noted that on the 7th day of life the newborn was found intense changes in the structure of the parenchyma of the thyroid gland of animals of the experimental group: increased relative percentage of follicle cavity due to increased number of large and medium, some follicles had no resorption vacuoles which was accompanied by a slowdown in the excretion of hormones into the bloodstream and led to overstretching of the follicles and, as a consequence, to the flattening of the thyroid epithelium. Intrauterine administration of dexamethasone leads to prenatal acceleration of structure formation, folliculogenesis and enhancement of hormone-producing function, which is confirmed by the peculiarities of immunohistochemical expression of TgAb. By the end of the neonatal period in rats prenatally exposed to dexamethasone, the thyroid gland is depleted of compensatory-reactive internal reserves, which is morphologically and immunohistochemically manifested by signs of hypofunction and hypertrophy. Thus, detected in the thyroid glands of animals prenatally exposed to dexamethasone, 
aberration of cytoplasmic expression of $\mathrm{TgAb}^{+}$, intensification of colloidal expression of $\mathrm{TgAb}+$, flattening of thyroid epithelium, and the absence of resorption vacuoles are signs of impaired hormone-forming function, which is the morphological basis for the development of hypofunctional states and requires further study.

Keywords: thyroid gland, immunohistochemistry, thyrocyte, thyroglobulin, dexamethasone.

\section{Introduction}

Synthetic glucocorticoids, such as dexamethasone, are used in clinical practice to accelerate fetal maturation in pregnant women at risk of preterm birth [1, 9, 18]. Antenatally, glucocorticoids mimic the effect of endogenous elevation of cortisol in blood plasma, which is usually observed in the fetus in the period close to delivery $[1,6]$. In humans and other mammalian species, the surge of cortisol in the body causes structural and functional changes in the tissues of the fetus, preparing it for childbirth and extrauterine life $[3,12]$.

Scientists $[2,13,19]$ experimentally prove that as a result of the influence of glucocorticoids on the body of animals in the postnatal ontogenesis of different age periods in the thyroid gland identified morphological signs that indicate a decrease in its functional activity. It is established that postnatal use of glucocorticoids leads to changes in the structure of the thyroid gland of rats of different ages, which are observed at all levels of its structural organization. The clinical manifestation of these changes depends on the age of the animals, the type and duration of exposure to drugs (hydrocortisone or dexamethasone). At the end of the readaptation period, the restoration of the morphofunctional state of the thyroid gland is realized more effectively in adult rats $[11,19]$. Glucocorticoids affect fetal growth and tissue formation, as they are key endogenous factors that determine fetal cell maturation [10, 20, 21]. Most scientific papers on the prenatal action of exogenous glucocorticoids [2, 12, 16] have a physiological and pathophysiological direction without morphological basis of the data.

Unfortunately, despite the large number of studies on the effects of glucocorticoids on the fetus, there is almost no data on the prenatal effect of dexamethasone on the synthesis and resorption of thyroglobulin by thyroid thyrocytes in the postnatal period.

The aim of the study was to determine the immunohistochemical features of the expression and distribution of antibodies to thyroglobulin in the thyroid glands of newborn rats in normal and after prenatal exposure to dexamethasone.

\section{Materials and methods}

The study material was the thyroid glands of Wistar rats aged 1 to 7 days of postnatal development (54 animals), 6 animals in each group. Three groups of animals on the $1 \mathrm{st}, 3 \mathrm{rd}$, and 7 th days of the postnatal period of life were studied: I group - intact animals (norm); II group - control, animals which were injected with $0.9 \% \mathrm{NaCl}$ solution on the 18th day of the dated pregnancy; III group - experimental animals, which were injected with a solution of dexamethasone at a dilution of 1:40 on the 18th day of dated pregnancy (Ukrainian patent №112288). Dexamethasone and $0.9 \% \mathrm{NaCl}$ solution were administered surgically to the fetus during laparotomy, by intrauterine, transdermal subcutaneous injection into the interscapular area at a dose of $0.05 \mathrm{ml}$.

The keeping and care of animals and all other manipulations were carried out in accordance with the provisions of the "European Convention for the Protection of Vertebrate Animals Used for Experimental and Other Scientific Purposes" (Strasbourg, 1985), the Helsinki Declaration of the General Assembly of the World Medical Association (2000), "General Ethical Principles of Animal Experiments", adopted by the First National Congress on Bioethics (Kyiv, 2001), the Law of Ukraine "On Protection of Animals from Cruelty" (dated 21.02.2006 №3447-IV, edition dated 09.12.2015, reason 766-19).

The thyroid complex with the tracheal area was fixed in a $10 \%$ solution of neutral buffered formalin during the day. The objects were filled into paraffin blocks by the conventional method. Histological sections 3-5 $\mu \mathrm{m}$ thick were stained with hematoxylin and eosin for viewing light microscopy.

Immunohistochemical examination was performed according to the Protocol recommended for a particular antibody of the manufacturer. Thyroglobulin Antibody $(2 \mathrm{H} 11)$ monoclonal antibodies: sc-51708 from Santa Cruz Biotechnology, Inc. were used to evaluate the morphological criteria of synthetic activity in the thyroid gland. using the method of indirect staining with immunoperoxidase using

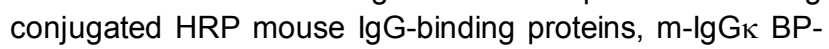
HRP, followed by incubation in a substrate of peroxidase and a mixture of chromogen DAB-3-diaminobenzidine tetrachloride, by staining the nuclei with Mayer's Hematoxylin Solution, dehydration, enlightenment and imprisonment in balm.

The result was regarded as positive in the precipitation of chromogen salts in the form of a specific reaction (nuclear, cytoplasmic reaction depending on the location of the antigen). The intensity of benzidine label deposition was evaluated by photographic digital morphometry using the Image $\mathrm{J}$ program in each case in 5 standardized fields of view of a microscope with a magnification of 400 (lens $x 40$, eyepiece $\mathrm{x} 10$ ), where the intensity of marker expression was determined and quantified in conventional units of optical density negative reaction - 0-20; low level of 
expression - 21-50; moderate level of expression - 51-100; high level of expression - more than 100.

In order to control the method, a series of studies was conducted using positive and negative samples, which served as standards.

Photo documentation of the studied objects was performed using a Primo Star microscope (Carl Zeiss, Germany) using an AxioCam camera, using the Zeiss Zen program (2011).

\section{Results}

Examination microscopy of serial histological sections of the thyroid gland of intact and control groups of 1-3 days of life revealed that the parenchyma of the organ was represented by follicles, mainly colloidal type of secretion and interfollicular thyrocytes. The cavity in the center of most follicles was not visualized, but single hollow follicles of colloidal type of small and medium diameters were chaotically located subcapsularly in the peripheral zone of the organ. At the same time, in the experimental group animals that received dexamethasone prenatally, the parenchyma of the gland looked more developed follicularly, which was expressed in the presence of hollow follicles with oxyphilically stained colloid with marginal vacuolation on the periphery of the lobe. The size of the thyroid follicles of the animals of the experimental group was significantly larger (1.6 times) compared with the control and intact groups, similar parameters of which did not differ significantly. The expression of antibodies to thyroglobulin $(\operatorname{TgAb})$ in the thyroid gland of animals of the intact and control groups is moderate and is visualized in the cytoplasm of thyrocytes, in hollow follicles - in the colloid.

In the thyroid glands of animals of the experimental group, TgAb expression in the colloid of hollow follicles is uneven and has a foamy appearance due to the large number of resorption vacuoles, while in most follicular thyrocytes cytoplasmic expression of $\mathrm{TgAb}$ was not detected immunohistochemically.

On the third day of postnatal life in the thyroid gland of animals of groups I and II, mostly single capsular follicles with colloidal type of secretion appear subcapsularly (Fig. 1A). Part of the spherical follicles was irregularly shaped. Cubic follicular thyrocytes lie on the basement membrane, tightly connected. There is a moderate, sometimes intense cytoplasmic TgAb expression of follicular thyrocytes (Fig. 1A). Immunohistochemically in the cavity of the follicles there is thyroglobulin with intense parietal expression and moderate central. Small marginal vacuoles of colloid resorption are partially visualized in single follicles of medium diameter. In the thyroid gland of experimental animals prenatally exposed to dexamethasone, hollow colloid-type follicles were distributed throughout the body. The follicles were mostly of medium diameter, irregular in shape and localized under the capsule. The intensity of $\mathrm{TgAb}$ expression is uneven throughout the follicle cavity, especially parietal in the area of resorption vacuoles. The cytoplasmic $\mathrm{TgAb}$ reaction is weak, visualized in single follicular thyrocytes in the apical part of the cells.

On the seventh day of life at the end of the neonatal period morphologically, the parenchyma of the thyroid gland had the following characteristics: the follicle wall was formed by prismatic and cubic thyrocytes located on the basement membrane, thyrocyte nuclei are rounded, large, well visualized nucleoli. A colloid secreted by thyrocytes and fills the follicle cavity moderately with $\mathrm{TgAb}+$, mainly with parietal vacuolation (see Fig. 1A). On the 7th day of the postnatal period of ontogenesis there are intense changes in the morphological structure of the thyroid glands of animals of group III: the number of follicles of large and medium diameter increases, accompanied by a decrease
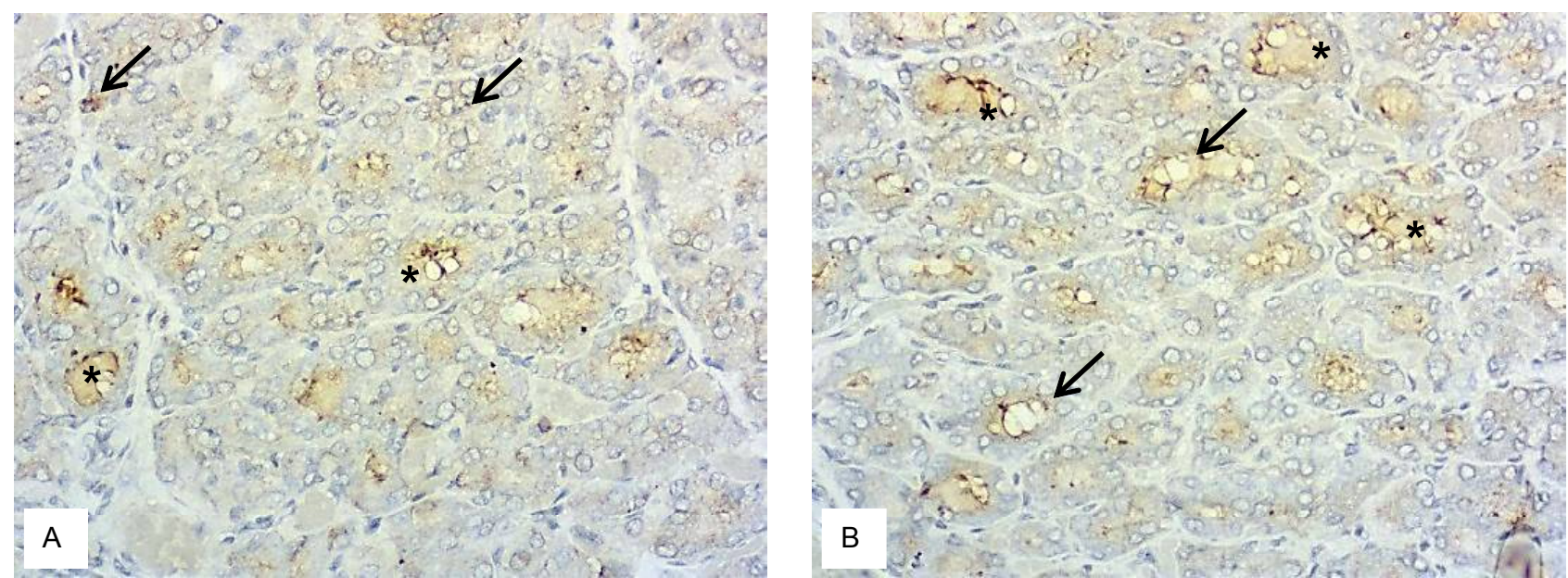

Fig. 1. Immunohistochemical expression of antibodies to thyroglobulin in the peripheral part of the thyroid gland of newborn Wistar rats on the third day of life. $\mathrm{x} 400$. A - thyroid gland of the control group rats; weak cytoplasmic expression of $\mathrm{TgAb}^{+}$in thyrocytes of colloidtype thyroid follicles is visualized (indicated by arrows); asterisks indicate the expression of thyroglobulin colloid of the follicular cavity. $B$ - thyroid gland of animals of the experimental group, which were prenatally administered dexamethasone; arrows indicate vacuoles of colloid resorption $(\mathrm{TgAb}-)$; asterisks indicate $\mathrm{TgAb}^{+}$follicles with intense colloidal expression. 

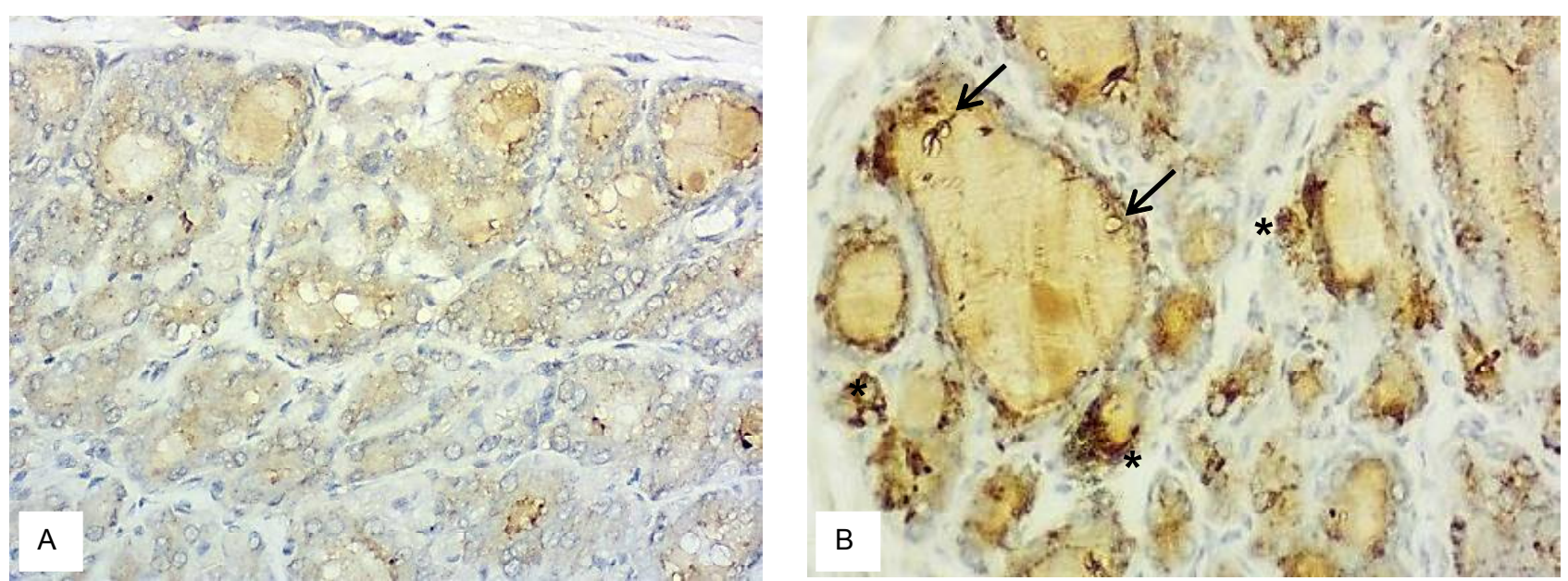

Fig. 2. Immunohistochemical expression of antibodies to thyroglobulin in the peripheral part of the thyroid gland of newborn Wistar rats on the seventh day of life. $\times 400$. A - thyroid gland of the control group rats; low cytoplasmic and moderate colloidal expression of $\mathrm{TgAb}{ }^{+}$ is visualized. B - thyroid gland of animals of the experimental group, which were prenatally administered dexamethasone; intensive cytoplasmic and moderately intense colloidal $\mathrm{TgAb}^{+}$expression; arrows indicate vacuoles of resorption of $\mathrm{TgAb}^{+}$colloid; asterisks indicate thyrocytes with intense cytoplasmic expression of $\mathrm{TgAb}^{+}$.

in thyroid epithelium and an increase in colloid area. Parietal vacuolation in such follicles is absent or single vacuoles are found (Fig. 2B). There are follicles of different shapes: round, elongated, polygonal, which are mosaically distributed over the entire area of the gland.

\section{Discussion}

Analysis of thyroid micropreparations of intact and control rats showed the normality of the vector of thyroglobulin synthesis and its accumulation, which is expressed by the immunohistochemical expression of antibodies to thyroglobulin $\left(\operatorname{TgAb} b^{+}\right.$.

During the neonatal period in rats normally continues morphological development and maturation of hormoneproducing structures. This process dynamically and evenly covers all parts, both intracellular and extracellular. Because thyroid hormones promote the development of other organs and structures of the body, they are intensively realized by the body on the way of adaptation of the body to extrauterine life and the development of the body as a whole. This is confirmed by the available data on the expression of antibodies to thyroglobulin and vacuolization of colloid, and similar data were obtained by scientists in control rats in an experimental study of the effects of chronic stress on morphological transformations in thyroid glands at an early age [17].

Prenatal administration of dexamethasone leads to intensification of the processes of morphological development of hormone-producing structures (follicles and follicular epithelium), production, resorption and iodination of thyroglobulin. This trend is confirmed in their studies by other scientists, who experimentally found that in fetuses of sheep induced by maternal dexamethasone, there was an increase in circulating thyroid hormone triiodothyronine (T3) [8]. They proved that maternal dexamethasone treatment largely mimics the effects of endogenous glucocorticoids on thyroid hormone metabolism in the near future and can promote fetal maturation by stimulating thyroid hormone activity in utero. This is also evidenced by our data from immunohistochemical studies, found on 1-3 day of the neonatal period. But at the end of the neonatal period (on the 7 th day of life) intense transformations in the structures of the parenchyma of the thyroid glands of animals of the experimental group were revealed: the relative percentage of the area of the follicle cavity increases due to an increase in the number of large and medium follicles, in some follicles resorption vacuoles disappear, which is accompanied by a slowdown in the excretion of hormones into the bloodstream and leads to overstretching of the follicles and, as a consequence, to the flattening of the thyroid epithelium. Such morphological changes are explained and correlated with the ultrastructural features of thyrocytes studied by electron microscopic examination after postnatal administration of prednisone [5], manifested in the accumulation of colloidal droplets in the cytoplasm of follicles and proves the fact that prednisone can reduce the basal secretion of thyroid hormones by inhibiting lysosomal hydrolysis of colloid in follicular cells. That is, the consequence of severe exogenous or endogenous hypercorticism is moderate hypothyroidism [5, 7, 15, 22].

Stagnation of secretion in the cavity of the follicles leads to stretching of its walls, causing signs of hypertrophy. Aberrant cytoplasmic expression of $\mathrm{TgAb}^{+}$is a sign of impaired hormone-forming function of thyrocytes, which is the morphological basis for the development of hypofunctional states, which explains the data obtained by scientists $[1,16,19]$. In the study of the effect of elevated concentrations of endogenous glucocorticoids in chronic stress on the thyroid gland at an early age, it was noted that 
the greatest sensitivity to follicular compartment was found during breastfeeding, which is characterized by structural changes in it, indicating inhibition of its activity [4, 14]. It should be noted that a number of scientists in their immunohistochemical studies also note that under chronic stress, antibodies to thyroglobulin intensely stain the cytoplasm of follicular thyrocytes and are poorly uniformly expressed by colloid.

Obtained by us data that after prenatal action of dexamethasone at the end of the neonatal period in the thyroid gland are formed immunomorphological features of the hypofunctional picture, the vector of morphological changes correlates with the data of other scientists $[7,8$, 22]. These studies showed that during the postnatal period due to the effects of glucocorticoids on animals of different ages, young animals were more sensitive, and after the introduction of dexamethasone lactating females in the offspring were changes in the architecture and functional activity of the thyroid gland. Thus, regardless of the route of administration, dexamethasone can cause in the thyroid glands of organisms that grow and form, such morphological signs that indicate a decrease in the functional activity of the thyroid gland, namely: reduced organometric parameters, delayed differentiation of parenchyma into lobules, increased size, flattening of the follicular epithelium with a decrease in its height,

\section{References}

[1] Asztalos, E. (2012). Antenatal Corticosteroids: A Risk Factor for the Development of Chronic Disease. J. Nutrition Metab., 2012, 9. doi: 10.1155/2012/930591

[2] Brown, R.S., Shalhoub, V., Coulter, S., Alex, S., Joris, I., De Vito, W. ... Stein, G.S. (2000). Developmental regulation of thyrotropin receptor gene expression in the fetal and neonatal rat thyroid: relation to thyroid morphology and to thyroid-specific gene expression. Endocrinology, 141(1), 340-345. doi: 10.1210/ endo.141.1.7258

[3] Chen, M., \& Zhang, L. (2011). Epigenetic mechanisms in developmental programming of adult disease. Drug Discov. Today, 16(23-24), 1007-1018. doi: 10.1016/ j.drudis.2011.09.008

[4] Dawood, M., \& Alkalby, J. (2020). Effect of treatment with dexamethasone on thyroid function in lactating female rats. Basrah Journal of Veterinary Research, 19, 331-345.

[5] Elmahdi, B., Hassan, M., \& El-Bahr, S. (2016). Effect of prednisolone on thyroid and gonadotrophic hormones secretion in male domestic rabbits. Thyroid Research and Practice, 13(3), 136. doi: 10.4103/0973-0354.193135

[6] Elsnosy, E., Shaaban, O.M., Abbas, A.M., Gaber, H.H., \& Darwish, A. (2017). Effects of antenatal dexamethasone administration on fetal and uteroplacental Doppler waveforms in women at risk for spontaneous preterm birth. Middle East Fertility Society Journal, 22(1), 13-17. doi: 10.1016/j.mefs.2016.09.007

[7] Fomina, К.A. (2006). Морфометрические показатели щитовидной железы крыс различного возраста при воздействии на их организм дексаметазона [Morphometric parameters of the thyroid gland of rats of different ages when exposed to dexamethasone]. Український морфоологічний альманах - Ukrainian Morphological Almanac, 4(3), 96-99.

[8] Forhead, A.J., Jellyman, J.K., Gardner, D.S., Giussani, D.A., compaction of the colloid in combination with a decrease in the size of the nuclei of thyrocytes.

The question of the occurrence in the thyroid glands of animals prenatally exposed to dexamethasone, signs of violation of the hormone-forming function of thyrocytes needs further study.

\section{Conclusions}

1. Intrauterine administration of dexamethasone leads to prenatal acceleration of structure formation, folliculogenesis and enhancement of hormone-producing function, which is confirmed by the peculiarities of immunohistochemical expression of TgAb.

2. By the end of the neonatal period in rats prenatally exposed to dexamethasone, the thyroid gland is depleted of compensatory-reactive intraorgan reserves, which is morphologically and immunohistochemically manifested by signs of hypofunction and hypertrophy.

3. Detected in the thyroid glands of animals prenatally exposed to dexamethasone, aberrations of cytoplasmic expression of $\mathrm{TgAb}^{+}$, intensification of colloidal expression of $\mathrm{TgAb}^{+}$, flattening of thyroid epithelium and practically no resorption vacuoles are signs of violation of hormoneforming function of thyrocytes, which is the morphological basis for the development of hypofunctional states.

Kaptein, E., Visser, T.J., \& Fowden, A.L. (2007). Differential effects of maternal dexamethasone treatment on circulating thyroid hormone concentrations and tissue deiodinase activity in the pregnant ewe and fetus. Endocrinology, 148(2), 800805. doi: 10.1210/en.2006-1194

[9] Haram, K., Mortensen, J. H., Magann, E.F., \& Morrison, J.C. (2017). Antenatal corticosteroid treatment: factors other than lung maturation. The Journal of Maternal-Fetal \& Neonatal Medicine, 30(12), 1437-1441. doi: 10.1080/ 14767058.2016.1219716

[10] Hu?as-Stasiak, M., Dobrowolski, P., \& Tomaszewska, E. (2016). Prenatally administered dexamethasone impairs folliculogenesis in spiny mouse offspring. Reproduction, Fertility and Development, 28(7), 1038-1048. doi: 10.1071/ RD14224

[11] Kashchenko, S.A., \& Goncharova, M.V. (2013). Ультрамикроскопические изменения щитовидной железы крыс после иммуносупрессии [Submicroscopic changes in the thyroid gland of rats after the immunosuppression]. Морфологія Morphologia, 7(3), 49-53.

[12] Lv, F., Wan, Y., Chen, Y., Pei, L., Luo, D., Fan, G. ... \& Wang, H. (2018). Prenatal dexamethasone exposure induced ovarian developmental toxicity and transgenerational effect in rat offspring. Endocrinology, 159(3), 1401-1415. doi: 10.1210/ en.2018-00044

[13] Moisiadis, V.G., \& Matthews, S.G. (2014). Glucocorticoids and fetal programming part 1: outcomes. Nat. Rev. Endocrinol., 10(7), 391-402. doi: 10.1038/nrendo.2014.73

[14] Nadolnik, L.I. (2010). Стресс и щитовидная железа [Stress and thyroid]. Биомедицинская химия - Biomedical Chemistry, 56(4), 443-456.

[15] Rizzo, L.F., Mana, D.L., \& Serra H.A. (2017). Drug-induced 
hypothyroidism. Medicina, 77(5), 394-404. PMID: 29044016

[16] Seckl, J.R. (2004). Prenatal glucocorticoids and long-term programming. Eur J Endocrinol, 151(3), 49-62. doi: 10.1530/ eje.0.151u049

[17] Smirnova, T.S., Degtyar, Yu.V., Sharaevskaya, M.V., \& Kapitonova, M.Yu. (2008). Иммуногистохимическая характеристика щитовидной железы при хроническом стресce [Immunohistochemical characteristics of the thyroid gland in chronic stress]. Вестник Волгоградского государственного медицинского университета - Bulletin of the Volgograd State Medical University, 4(28), 51-54.

[18] Todosenko, N.M., Koroleva, Yu.A., \& Khazyakhmatova, O.H. (2017). Геномные и негеномные эфффекты глюкокортикоидов [Genom and nongenom effects of glucocorticoids]. Гены и клетки - Gens and Cells, 12(1), 27-33. doi: 10.23868/ 201703003

[19] Voloshin, N.A., Sapyanova, O.K., \& Kireenkova, K.V. (2012). Вікові зміни щитоподібної залози білих щурів після дії гідрокортизону на організм [Age changes in thyroid gland white rats under influence on the organism hydrocortisone]. Український медичний альманах - Ukrainian Medical Almanac, 15(6), 190-191.
[20] Voloshyn, М.A., \& Bohdanov, P.V. (2017). Особливості клітинного складу печінки щурів з першого до третього місяця післянатального життя в нормі та після внутрішньоутробного введення антигену та глюкокортикоїду [Peculiarities of rat liver cell composition from the first to the third month of postnatal life are normal and after intrauterine administration of antigen and glucocorticoid]. Актуальні питання медичної науки та практики - Current Issues of Medical Science and Practice, 84(1), 11-16.

[21] Yuan, H.J., Han, X., He, N., Wang, G.L., Gong, S., Lin, J. ... Tan, J.H. (2016). Glucocorticoids impair oocyte developmental potential by triggering apoptosis of ovarian cells via activating the Fas system. Scientific Reports, 6(1), 1-12. doi: 10.1038/ srep24036

[22] Zagrebin, V.L., Kapitonova, M.Yu., Morozova, Z.Ch., \& Smirnova, T.S. (2007). Морфологические аспекты адаптации эндокринной системы к действию стресса в раннем постнатальном онтогенезе [Morphological aspects of adaptation of the endocrine system to the action of chronic stress in early postnatal ontogenesis]. Успехи современного естествознания - Advances in Modern Natural Science, (1), 64-65.

\section{ІМУНОГІСТОХІМІЧНІ ОСОБЛИВОСТІ ЕКСПРЕСІЇ ТА РОЗПОДІЛУ АНТИТІЛ ДО ТИРОГЛОБУЛІНУ В ЩИТОПОДІБНИХ ЗАЛОЗАХ НОВОНАРОДЖЕНИХ ЩУРІВ ПІСЛЯ ПРЕНАТАЛЬНОГО ВПЛИВУ ДЕКСАМЕТАЗОНУ \\ Федосєєва О.В., Потоцька О.І.}

У клінічній практиці синтетичні глюкокортикоїди, такі як дексаметазон, використовують для прискорення дозрівання плода у вагітних жінок з ризиком передчасних пологів. Підвищення концентрації кортизолу в організмі людини та інших видів ссавців нерідко викликає структурні та функціональні зміни в тканинах плода, готуючи його до пологів та позаутробного життя, але вони можуть мати віддалені наслідки в структурній організації органів постнатально. Попри велику кількість проведених досліджень щодо впливу глюкокортикоїдів на плід майже відсутні дані з пренатального впливу дексаметазону на процеси синтезу та резорбиї тироглобуліну тироцитами щитоподібної залози у постнатальному періоді життя. Тому метою дослідження було визначення імуногістохімічних особливостей експресії та розподілу антитіл до тироглобуліну в щитоподібних залозах новонароджених щурів в нормі та після пренатального впливу дексаметазону. Матеріалом дослідження були щитоподібні залози щурів лінії Вістар у віці від 1 до 7 доби постнатального розвитку (54 тварини): I гр. - інтактні тварини (норма); II гр. - контрольна, тваринам котрої вводили 0,9\% розчин $\mathrm{NaCl}$ в дозі 0,05 мл кожному плоду на 18 добу датованої вагітності; III - експериментальні тварини, яким вводили розчин дексаметазону у розведенні 1:40 в дозі 0,05 мл кожному плоду на 18 добу датованої вагітності оперативно під час лапаротомії, шляхом крізьматкової, крізьоболонкової підшкірної ін'єкції у міжлопаткову ділянку (патент України №112288). Для імуногістохімічного дослідження використовували моноклональні антитіла Thyroglobulin Antibody (2H11): sc-51708 фiрми Santa Cruz Biotechnology, Inc. Фотодокументацію досліджуваних об'єктів виконано з використанням мікроскопу "Primo Star" (Carl Zeiss, Німеччина) з використанням камери AхіоCат за допомогою програми Zeiss Zen (2011). Аналіз мікропрепаратів щитоподібних залоз щурів інтактної та контрольної групи показав незмінність синтезу тироглобуліну та його акумуляції, що виражалось достатньою імуногістохімічною експресією антитіл до тироглобуліну $\left(T g A b^{+}\right)$. Пренатальне введення дексаметазону призводить до інтенсифрікації процесів морфологічного розвитку гормон-продукуючих структур (фолікулів та фолікулярного епітелію), продукції, резорбції та йодинізації тироглобуліну. Про це свідчать дані імуногістохімічного дослідження, виявлені у 1-3 добу періоду новонародженості. Слід відмітити, що на 7 добу життя новонародженого були виявлені інтенсивні перетворення у структурі паренхіми щитоподібної залози тварин експериментальної групи, а саме: збільшувався відносний відсоток площі порожнини фолікулів за рахунок збільшення кількості великих та середніх, у частини фолікулів не було резорбційних вакуолей, що супроводжувалося уповільненням виведення гормонів до кровотоку й призводило до перерозтягнення фолікулів $і$, як наслідок, до сплощення тиреоїдного епітелію. Внутрішньоплідне введення дексаметазону призводить до пренатального прискорення структуроутворення, фолікулогенезу та підсилення гормон-продукуючої функції, що підтверджується особливостями імуногістохімічної експресії TgAb. До завершення періоду новонародженості у щурів, пренатально експонованих дексаметазоном, у щитоподібній залозі виснажуються компенсаторно-реактивні внутрішньоорганні резерви, що морфологічно та імуногістохімічно проявляється ознаками гіпофункції та гіпертрофрії. Таким чином, виявлені у щитоподібних залозах тварин, пренатально експонованих дексаметазоном, аберантність цитоплазматичної експресії TgAb+, інтенсифікація колоїдної експресії $\mathrm{TgAb}^{+}$, сплощення тиреоїдного епітелію та відсутність вакуолей резорбції $є$ ознаками порушення гормон-утворюючої функції тироцитів, що є морфологічним підгрунттям до розвитку гіпофункціональних станів, що потребує подальшого вивчення.

Ключові слова: щитоподібна залоза, імуногістохімія, тироцит, тироглобулін, дексаметазон. 